\title{
PRODUCTION OF NITROGEN OXIDES BY LIGHTNING AND CORONAE DISCHARGES IN SIMULATED EARLY EARTH, VENUS AND MARS ENVIRONMENTS
}

\author{
D. Nna Mvondo ${ }^{1,2}$, R. Navarro-González ${ }^{1}$, C.P. $\mathrm{McKay}^{3}$, P. Coll ${ }^{2}$ and F. Raulin ${ }^{2}$ \\ ${ }^{1}$ Laboratorio de Química de Plasmas y Estudios Planetarios, Instituto de Ciencias Nucleares, Universidad \\ Nacional Autónoma de México, Circuito Exterior, Ciudad Universitaria, Apartado Postal 70-543, México D.F. \\ 04510, México \\ ${ }^{2}$ Laboratoire Interuniversitaire des Systèmes Atmosphériques, Universités Paris 12 et 7, 61 av. Général de \\ Gaulle, 94010 Créteil Cedex, France \\ ${ }^{3}$ Space Science Division, NASA-Ames Research Center, Moffett Field, CA 94035-1000, USA
}

\begin{abstract}
We present measurements for the production of nitrogen oxides $\left(\mathrm{NO}\right.$ and $\mathrm{N}_{2} \mathrm{O}$ ) in $\mathrm{CO}_{2}-\mathrm{N}_{2}$ mixtures that simulate different stages of the evolution of the atmospheres of the Earth, Venus and Mars. The nitrogen fixation rates by two different types of electrical discharges, namely lightning and coronae, were studied over a wide range in $\mathrm{CO}_{2}$ and $\mathrm{N}_{2}$ mixing ratios. Nitric oxide $(\mathrm{NO})$ is formed with a maximum energy yield estimated to be $\sim 1.3 \times 10^{16}$ molecule $\mathrm{J}^{-1}$ at $80 \% \mathrm{CO}_{2}$ and $\sim 1.3 \times 10^{14}$ molecule $\mathrm{J}^{-1}$ at $50 \% \mathrm{CO}_{2}$ for lightning and coronae discharges, respectively. Nitrous oxide $\left(\mathrm{N}_{2} \mathrm{O}\right)$ is only formed by coronae discharge with a maximum energy yield estimated to be $\sim 1.2 \times 10^{13}$ molecule $\mathrm{J}^{-1}$ at $50 \% \mathrm{CO}_{2}$. The pronounced difference in $\mathrm{NO}$ production in lightning and coronae discharges and the lack of formation of $\mathrm{N}_{2} \mathrm{O}$ in lightning indicate that the physics and chemistry involved in nitrogen fixation differs substantially in these two forms of electric energy.
\end{abstract}

\section{INTRODUCTION}

Nitrogen fixation by natural abiotic sources on the contemporaneous Earth has been studied with great interest since the end of the 70's. Dinitrogen is converted in the atmosphere into $\mathrm{NO}_{\mathrm{x}}\left(\mathrm{NO}+\mathrm{NO}_{2}\right)$ and $\mathrm{N}_{2} \mathrm{O}$, forms known as fixed nitrogen, by energetic processes. The production of $\mathrm{NO}_{\mathrm{x}}$ and $\mathrm{N}_{2} \mathrm{O}$ in the atmosphere is of major environmental importance. $\mathrm{NO}_{\mathrm{x}}$ has a key role in the photochemistry of the atmosphere leading to the production of tropospheric ozone and controlling the levels of stratospheric ozone. Moreover the removal of $\mathrm{NO}_{\mathrm{x}}$ by acid precipitation (in the form of nitrous and nitric acids) is a source of fixed nitrogen for the biosphere (Stark et al., 1996). The amount of nitrogen fixed by tropospheric processes plays a major role in the equilibrium of the biosphere. This is because nitrogen fixation requires a great deal of energy to break the $\mathrm{N} \equiv \mathrm{N}$ bond $\left(9.45 \mathrm{MJ} \mathrm{mol}^{-}\right.$ ${ }^{1}$ ). The ability to fix nitrogen biologically is restricted to bacteria (Postgate, 1987). $\mathrm{N}_{2} \mathrm{O}$ is a stable trace gas in the troposphere where it plays an important greenhouse effect. Its sink is its photodestruction in the stratosphere where it contributes to ozone depletion (Adema et al., 1990).

Among the natural sources of atmospheric $\mathrm{NO}_{\mathrm{x}}$, lightning has been proposed to be significant (Von Liebig, 1827; Chameides et al., 1977) and possibly the major pathway by which nitrogen is fixed to $\mathrm{NO}_{\mathrm{x}}($ Noxon, 1976; Zipf and Dubin, 1976; Griffing, 1977; Chameides, 1979a; Franzblau and Popp, 1989). The production yield of $\mathrm{NO}_{\mathrm{x}}$ by lightning discharge has been estimated by field observations and measurements (Noxon, 1976, 1978; Borucki and Chameides, 1984; Chameides et al., 1987; Ridley et al, 1987; Franzblau and Popp, 1989; Biazar and McNider, 1995), by laboratory discharge experiments (Chameides et al., 1977; Hill et al., 1988; Martinez and Brandvold, 1996; Stark et al., 1996; Wang et al., 1998) and also by theoretical modeling (Chameides et al., 1977; Chameides, 1979a; Yung and McElroy, 1979; Hill et al., 1980; Chameides and Walker, 1981; Bhetanabhotla et al., 1985; 
Coppens et al., 1998). From these results the estimated energy yield of NOx production extends from $\sim 6 \times 10^{15}$ to $\sim 2 \times 10^{17}$ molecule $\mathrm{J}^{-1}$, and the corresponding global production rate varies from $\sim 9 \times 10^{7}$ up to $\sim 1 \times 10^{14} \mathrm{~g} \mathrm{~N} \mathrm{yr}^{-1}$.

Production of $\mathrm{N}_{2} \mathrm{O}$ has been observed in lightning (Levine et al., 1981) and in coronae (Brandvold et al., 1996) discharges during thunderstorms. $\mathrm{N}_{2} \mathrm{O}$ has also been detected in laboratory discharges (Donohoe et al., 1977; Levine et al., 1979; Hill et al., 1988; Brandvold et al., 1989; Fraser et al., 1990). Based on laboratory measurements and theoretical calculations (Chameides, 1979a, 1979b; Hill et al., 1984; Bhetanabhotla et al., 1985) it has been estimated a production efficiency from $\sim 3 \times 10^{12}$ up to $\sim 1.5 \times 10^{13}$ molecule $\mathrm{J}^{-1}$ in the lightning discharge and from $3 \times 10^{15}$ up to $\sim 1 \times 10^{17}$ molecule $\mathrm{J}^{-1}$ for coronae processes.

$\mathrm{NO}$ appears to be produced in a large extent inside the lightning channel with $\mathrm{NO}_{2}$ being formed mostly as a secondary product generated outside the lightning channel with the reaction of $\mathrm{NO}$ with ozone. Ozone and $\mathrm{N}_{2} \mathrm{O}$ seem to be formed preferentially in the corona sheath surrounding the lightning channel (Hill et al., 1980) or in point discharges in the ground (Brandvold et al., 1996).

Electrical discharges have also been proposed to be a relevant source of fixed nitrogen in the early Earth's troposphere (Yung and McElroy, 1979; Chameides and Walker, 1981; Kasting and Walker, 1981; Mancinelli and McKay, 1988). In these theoretical studies, it has been concluded that, in the absence of biological perturbation, lightning could have provided a source of fixed nitrogen necessary for the emergence of life. The only experimental report on the abiotic nitrogen fixation rate by lightning in a primitive terrestrial-type atmosphere is

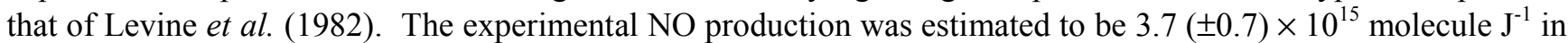
an atmosphere composed of $95.9 \% \mathrm{CO}_{2}, 3.97 \% \mathrm{~N}_{2}, 180 \mathrm{ppm} \mathrm{SO} 2,50 \mathrm{ppm} \mathrm{Ar}$, and $30 \mathrm{ppm} \mathrm{CO}$ that simulated the present atmosphere of Venus. Another related experimental study is that of Navarro-González et al. (1998b) for the production of nitric oxide by lightning inside explosive volcanic clouds of the early Earth.

The purpose of this work is to provide the first comprehensive experimental study of the nitrogen fixation rate by lightning and coronae discharges under conditions relevant to the early Earth, Venus and Mars in atmospheres containing various mixing ratios of $\mathrm{CO}_{2}$ and $\mathrm{N}_{2}$ as the main constituents.

\section{EXPERIMENTAL PROCEDURE}

Two electrical discharge processes were simulated in the $\mathrm{CO}_{2}-\mathrm{N}_{2}$ primitive atmospheres: cloud-to-ground lightning discharge and point discharges occurring on the ground (corona discharge). Cloud-to-ground lightning was simulated in the laboratory by a laser-induced plasma (LIP) that has been shown to be a good analog of the return-stroke of a lightning flash (Borucki et al., 1985; Borucki and McKay, 1987; Scattergood et al., 1989; Jebens et al., 1992) without introducing contamination from the electrodes as when simulated with arcs and sparks (Borucki et al., 1988). The laser used was a Q-switched Neodymium-YAG operating at a wavelength of $1.06 \mu \mathrm{m}$, a pulse energy of up to $0.6 \mathrm{~J}$, a pulse repetition rate of $10 \mathrm{~Hz}$, and a pulse duration of 5-7 ns. The temperature of the plasma has been determined to be about $20,000 \mathrm{~K}$ after $1 \mu$ s from ignition. A beam with $0.3 \mathrm{~J}$ per pulse was focused inside a closed 1.08 liter Pyrex flask with a plano-convex optical glass lens with a focal length of $5 \mathrm{~cm}$, expected to have a focal aberration of $\sim 10 \mu \mathrm{m}$. The power deposited into the system was determined calorimetrically. The energy dissipated per unit length in this simulated lightning was estimated to be $\sim 10^{4} \mathrm{~J} \mathrm{~m}^{-1}$, in close agreement with that from natural lightning (Hill, 1979).

The corona discharge was induced in a coaxial Pyrex reactor composed of a central tungsten rod (internal electrode) surrounded internally by a grounded stainless steel cylinder (ground electrode). The internal electrode was connected to a regulated high voltage DC power that allows for both positive and negative DC operation. The high power supply delivers a maximum current of $3 \mathrm{~mA}$ and a maximum voltage of $30 \mathrm{kV}$. The power dissipated through the system was determined electrically (Navarro-González et al. 1998a).

The simulated primitive atmospheres composed of $\mathrm{CO}_{2}\left(99.99 \%\right.$ purity) and $\mathrm{N}_{2}(99.999 \%$ purity) were prepared at various mixing ratios using a measuring and control gas blending system equipped with fast response mass flow control modules of $20 \mathrm{~cm}^{3} \mathrm{~min}^{-1}$ capacity. The reactor was evacuated to $10^{-7}$ bar and flushed twice with the gas mixture before filled up at 1 bar total pressure. The samples were irradiated at $20^{\circ} \mathrm{C}$ from 5 to 30 min for lightning discharge experiments and from $8 \mathrm{~min}$ to 2 hours for corona discharge experiments. After irradiation, the gas mixtures were analyzed using a gas chromatograph interfaced in parallel with a FTIR-detector and a quadrupole mass spectrometer equipped with electron impact and chemical ionization modes. The gases were injected into the gas chromatograph by an automatic six-port gas-sampling loop of $2 \mathrm{ml}$. Two capillary chromatographic columns were used for the separation of the products, a PoraPLOT Q fused-silica $(25 \mathrm{~m} \times 0.32$ $\mathrm{mm}$ I.D. $)$ and an Alumina/ $\mathrm{KCl}(50 \mathrm{~m} \times 0.32 \mathrm{~mm}$ I.D. $)$. The temperatures at the GC-MS and GC-FTIR interfaces 
and in the FTIR flow cell were $260^{\circ} \mathrm{C}$. The column program temperature was isothermal at $30^{\circ} \mathrm{C}$ for 4 min, and then a rate of $13^{\circ} \mathrm{C} \mathrm{min}^{-1}$ up to $240^{\circ} \mathrm{C}$, and finally isothermal for $5.62 \mathrm{~min}$. The carrier gas used was helium with a flow of $2 \mathrm{ml} \mathrm{min}^{-1}$.

\section{RESULTS AND DISCUSSION}

Analyses of the gas mixtures after irradiation showed the formation of nitric oxide in significant quantities in both lightning and corona discharge experiments. Nitrogen dioxide and ozone, if formed, were not detected by our analytical instrumentation since these reactive gases decomposed during gas chromatographic analysis when using PoraPLOT columns. $\mathrm{NO}_{2}$ is visually observed only if the sample is significantly overexposed to LIPs. An interesting result is the production of nitrous oxide only in the cold plasma discharge. This observation is consistent with the theoretical (Hill et al., 1980, Hill and Rinker, 1981; Hill et al., 1984) and experimental studies (Donohoe et al., 1977) of nitrogen fixation in the contemporaneous Earth which demonstrated that $\mathrm{N}_{2} \mathrm{O}$ was produced in large extent in the corona regions and not in the lightning channel. Simultaneously carbon monoxide and molecular oxygen were detected in the samples after exposure to both electrical energy sources. These results are in agreement with Chameides et al. (1979c), who suggested that lightning might be a significant source of CO, $\mathrm{NO}$ and free oxygen on Venus. The detection of $\mathrm{CO}$ indicates that carbon dioxide is readily dissociated into carbon monoxide and oxygen by both forms of electrical energy: lightning and coronae discharges.

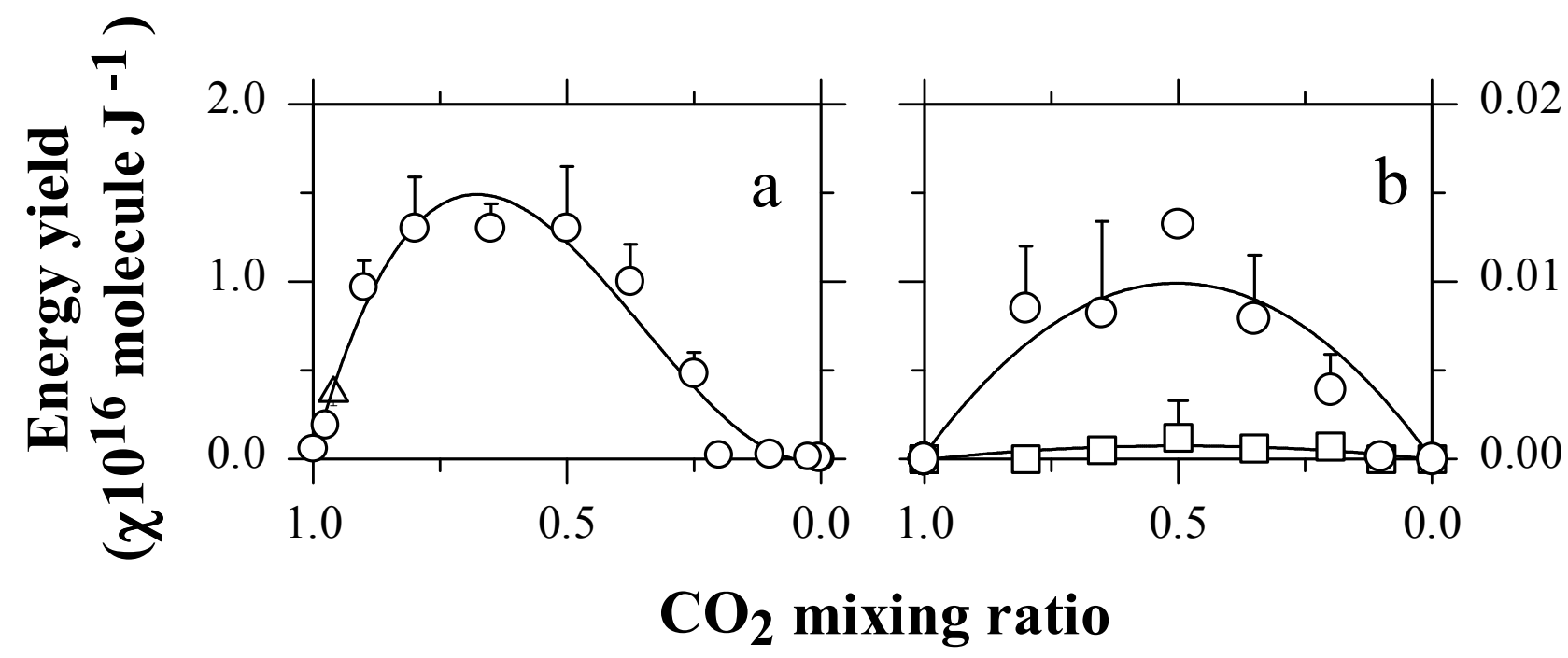

Fig. 1. Variation of nitrogen oxide yield as a function of the $\mathrm{CO}_{2}$ mixing ratio in lightning (a) and coronae (b) discharges in $\mathrm{CO}_{2}-\mathrm{N}_{2}$ atmospheres: $\bigcirc$ Nitric oxide, and $\square$ Nitrous oxide. For comparison, the experimental result from Venusinian lightning $(\triangle)$ obtained by Levine et al. (1982) is given.

The variations of the production rates of $\mathrm{NO}$ and $\mathrm{N}_{2} \mathrm{O}$ as a function of the $\mathrm{CO}_{2}$ mixing ratio $\left(\chi \mathrm{CO}_{2}\right)$ for lightning and coronae discharges are shown in Figure 1. Our results indicate that the energy yields of $\mathrm{NO}$ and $\mathrm{N}_{2} \mathrm{O}$ are very sensitive to the $\mathrm{CO}_{2}$ mixing ratios. In the case of lightning discharge, the NO yield increases from $\sim 1.9 \times 10^{15}$ molecule $\mathrm{J}^{-1}$ at $\chi \mathrm{CO}_{2} \sim 0.98$ to $\sim 1.3 \times 10^{16}$ molecule $\mathrm{J}^{-1}$ at $\chi \mathrm{CO}_{2} \sim 0.80$. This yield does not vary remarkably down to about $\chi \mathrm{CO}_{2} \sim 0.50$. This value is in good agreement with the theoretical estimations of Mancinelli and McKay (1988) and Chameides and Walker (1981) who estimated a NO production efficiency in the range of $1-3 \times 10^{16}$ molecule $\mathrm{J}^{-1}$ for $\chi \mathrm{CO}_{2}$ between 0.5 and 0.8 . At lower mixing ratios our experimental NO yield drastically decreases to $\sim 2.4 \times 10^{14}$ molecule $\mathrm{J}^{-1}$ at $\chi \mathrm{CO}_{2} \sim 0.20$ and then slowly diminishes to $\sim 1.1 \times 10^{14}$ molecule $\mathrm{J}^{-1}$ at $\chi \mathrm{CO}_{2} \sim 0.025$. Any further decrease in the atmospheric $\mathrm{CO}_{2}$ content has little impact at this point since the water vapor present in the atmosphere contributes with oxygen atoms for the production of NO, stabilizing it at about $7.0 \times 10^{13}$ molecule $\mathrm{J}^{-1}$. In the case of the corona discharge experiments, the maximum $\mathrm{NO}$ yield is 
$\sim 1.32 \times 10^{14}$ molecule $\mathrm{J}^{-1}$ for $\chi \mathrm{CO}_{2} \sim 0.5 . \quad \mathrm{N}_{2} \mathrm{O}$ has also a maximum production of $\sim 1.16 \times 10^{13}$ molecule $\mathrm{J}^{-1}$ at this mixing ratio. Our results clearly demonstrate that lightning is more efficient than coronae discharges in the synthesis of NO by about two orders of magnitude. For contemporaneous Earth, the lightning dissipation rate is about a factor of two higher than the coronae dissipation rate (Chyba and Sagan, 1991). If we assume that this ratio was similar for the early terrestrial planets, we could conclude that nitric oxide production by electrical processes in the early terrestrial planets was dominated by lightning discharge. This substantial discrepancy of the efficiency of NO synthesis by the two electrical energy sources can be explained by the physical differences encountered in lightning and corona discharges. Coronal discharges produce cold plasmas of highly superthermal electrons but the ions, neutral molecules and molecular fragments in the background gas remain near the ambient temperature. Therefore this system is not in thermal equilibrium. On the contrary, lightning discharges as simulated by LIPs produce hot plasmas in which the kinetic and excitation temperatures of all species are very high and are all in thermochemical equilibrium (Chyba and Sagan, 1991). Consequently, the chemistry occurring in hot plasmas appears to differ substantially from that in cold plasmas.

In this frame, we propose a reaction scheme for $\mathrm{NO}$ production in lightning discharge and in corona discharge. In addition we suggest a chemical mechanism to account for the production of $\mathrm{N}_{2} \mathrm{O}$ in corona discharge.

In the lightning discharge, nitrogen fixation is governed by high temperatures chemical reactions (Borucki and Chameides, 1984; Navarro-González et al., 1998b). The initial plasma temperature is higher than 30,000 K. As the gas cools down, the ions and electrons recombine leading to free radicals and stable molecules. As these species further cool down, they lead to the final products. The chemical mechanism needed to explain the formation of the final products is exclusively determined by radicals and/or stable molecule reactions occurring at high temperature. In $\mathrm{CO}_{2}-\mathrm{N}_{2}$ mixtures, the thermal dissociation of carbon dioxide occurs leading to the formation of atomic oxygen and carbon monoxide according the reaction 1. The main fate of atomic oxygen is its recombination to molecular oxygen via a third body (reaction 2).

$$
\begin{aligned}
& \mathrm{CO}_{2} \rightarrow \mathrm{O}+\mathrm{CO} \\
& \mathrm{O}+\mathrm{O}+\mathrm{M} \rightarrow \mathrm{O}_{2}+\mathrm{M}
\end{aligned}
$$

A small fraction of atomic oxygen reacts with molecular nitrogen leading to the formation of NO via a chain reaction (reactions 3 and 4). This reaction occurs only at temperatures above $1500^{\circ} \mathrm{C}$.

$$
\begin{aligned}
& \mathrm{O}+\mathrm{N}_{2} \rightarrow \mathrm{NO}+\mathrm{N} \\
& \mathrm{N}+\mathrm{CO}_{2} \rightarrow \mathrm{NO}+\mathrm{CO}
\end{aligned}
$$

In mixtures where $\mathrm{N}_{2}$ dominates, the reduction in the $\mathrm{NO}$ production is attributed to the efficient nitrogen recombination (reaction 5) making reaction 3 a negligible channel:

$2 \mathrm{~N}+\mathrm{N}_{2} \rightarrow 2 \mathrm{~N}_{2}$

The following reactions destroy NO:

$\mathrm{NO}+\mathrm{N} \rightarrow \mathrm{N}_{2}+\mathrm{O}$

$\mathrm{NO}+\mathrm{O} \rightarrow \mathrm{N}+\mathrm{O}_{2}$

In corona chemistry, it is recognized that the energy input leads to ionization and excitation and that most of species involved in the reactions are charged species and free radicals (Hill et al., 1984; Bhetanabhotla et al., 1985). Below we propose a chemical scheme that involves principally positive charged species.

In $\mathrm{CO}_{2}$ dominated mixtures, $\mathrm{CO}_{2}$ can be dissociated by the corona electrons by the following reaction:

$$
\begin{aligned}
\mathrm{CO}_{2} & \rightarrow \mathrm{CO}+\mathrm{O}^{+}+\mathrm{e}^{-} \\
& \rightarrow \mathrm{CO}^{+}+\mathrm{O}+\mathrm{e}^{-}
\end{aligned}
$$


Then $\mathrm{O}^{+}$can react with nitrogen to form $\mathrm{NO}^{+}$that lead to neutral $\mathrm{NO}$ via the reaction chain:

$\mathrm{O}^{+}+\mathrm{N}_{2} \rightarrow \mathrm{NO}^{+}+\mathrm{N}$

$\mathrm{NO}^{+}+\mathrm{e}^{-} \rightarrow \mathrm{NO}$

$\mathrm{N}_{2} \mathrm{O}$ can be formed by reaction of $\mathrm{NO}^{+}$with nitrogen atoms via the reactions 12 and 13 :

$\mathrm{NO}^{+}+\mathrm{N} \rightarrow \mathrm{N}_{2} \mathrm{O}^{+}$
$\mathrm{N}_{2} \mathrm{O}^{+}+\mathrm{e}^{-} \rightarrow \mathrm{N}_{2} \mathrm{O}$

In addition to reactions 8 to 12 , reactions 1,2 , and 4 to 7 can also take part in corona discharges. Reaction 3 , however, does not participate in corona processes because, in order for the rate constant to be significantly fast, the temperature of the gas must be higher than $1500^{\circ} \mathrm{C}$.

It is important to note that the above mechanism is only given as an illustration of the possible chemical processes that occur in both lightning and corona discharges and that it is important to develop a detail kinetic model to explain quantitatively the observed rates of nitrogen fixation. Nowadays there are still great uncertainties about the chemical mechanism of formation of $\mathrm{NO}$ and $\mathrm{N}_{2} \mathrm{O}$ by corona discharges.

\section{CONCLUSION}

We have experimentally examined the nitrogen fixation rate by thunderstorm lightning and coronae in the primitive atmospheres of the Earth, Venus and Mars. We conclude that nitric oxide could have been significantly produced in the primordial atmospheric environments by electrical discharges. Nitrous oxide is a minor product formed exclusively by coronae processes. This is the first report on the production of $\mathrm{N}_{2} \mathrm{O}$ in simulated experiments of the early telluric planets. Further studies are needed to determine its role in the atmosphere.

Currently, we are assessing the importance of nitrogen fixation by lightning on the global nitrogen cycle of the early telluric environments and its impact to the origin and evolution of life. Part of this work as it refers to the early Earth has been published elsewhere (Navarro-González et al., 2001). These results suggest that the development of biological nitrogen fixation arose in response to changes in atmospheric composition that resulted in a reduction in the production of abiotically fixed nitrogen by lightning.

\section{ACKNOWLEDGMENTS}

This work was supported by grants from the National Autonomous University of Mexico (DGAPAIN102796), the National Council of Science and Technology of Mexico (CONACyT 32531-T), the FrenchMexican scientific research program ECOS/CONACyT-SEP-ANNUIES (M97U01), and the NASA Astrobiology program.

\section{REFERENCES}

Adema, E.H., Ybema, J.R., Heeres, P., and Wegh, H.C.P., The Heterogeneous Formation of $\mathrm{N}_{2} \mathrm{O}$ in Air containing $\mathrm{NO}_{2}, \mathrm{O}_{3}$, and $\mathrm{NH}_{3}$, J. Atmos. Chem., 11, 255-269, 1990.

Bhetanabhotla, M.N., Crowell, B.A., Coucouvinos, A., Hill, R.D., and Rinker, R.G., Simulation of Trace Species Production by Lightning and Corona Discharge in Moist Air, Atmospheric Environment, 19, 1391-1397, 1985.

Biazar, A.P., and McNider, R.T., Regional Estimate of Lightning Production of Nitrogen Oxides, J. Geophys.Res., 100, 22.861-22.874, 1995.

Borucki, W.J., and Chameides, W.L., Lightning: Estimates of the Rates of Energy Dissipation and Nitrogen Fixation, Rev. Geophys. Space Phys., 22, 363-372, 1984.

Borucki, W.J., McKenzie, R.L., McKay, C.P., Duong, N.D., and Boac, D.S., Spectra of Simulated Lightning on Venus, Jupiter and Titan, Icarus, 64, 221-232, 1985.

Borucki, W.J., and McKay, C.P., Optical Efficiencies of Lightning in Planetary Atmospheres, Nature, 329, 509$510,1987$. 
Borucki, W.J., Giver, P., McKay, C. P., Scatterggod, T., and Parris, J.E., Lightning Production of Hydrocarbons and HCN on Titan: Laboratory Measurements, Icarus, 76, 125-134, 1988.

Brandvold, D.K., Martinez, P., and Dogruel, D., Polarity Dependence of $\mathrm{N}_{2} \mathrm{O}$ Formation from Corona Discharge, Atmos. Environ., 23, 1881-1883, 1989.

Brandvold, D.K., Martinez, P., and Hipsh, R., Field Measurements of $\mathrm{O}_{3}$ and $\mathrm{N}_{2} \mathrm{O}$ produced from Corona Discharge, Atmos. Environ., 30, 973-976, 1996.

Chameides, W.L., Stedman, D.H., Dickerson, P.R., Rusch, D.W., Cicerone, R.J., NOx Production in Lightning, $J$. Atmos. Sci., 34, 143-149, 1977.

Chameides, W.L., Effect of Variable Energy Input on Nitrogen Fixation in Instantaneous Linear Discharges, Nature, 277, 123-135, 1979a.

Chameides, W.L., The Implications of CO Production in Electrical Discharges, Geophys. Res. Lett., 6, 287-290, 1979b.

Chameides, W.L., Walker, J.C.G., and Nagy, A.F., Possible Chemical Impact of Planetary Lightning in the Atnospheres of Venus and Mars, Nature, 280, 820-822, 1979c.

Chameides, W.L., Walker, J.C.G., Rates of Fixation by Lightning of Carbon and Nitrogen in Possible Primitive Atmospheres, Origins of Life, 11, 291-302, 1981.

Chameides, W.L., Davis, D.D., Bradshaw, J., Rodgers, M., Sandholm, S., and Bai D.B., An Estimate of the NOx Production Rate in Electrified Clouds based on NO Observations from the GTE/CITE 1 Fall 1983 Field Operation, J. Geophys.Res., 92, D2, 2153-2156, 1987.

Chyba, C., and Sagan C., Electrical Energy Sources for Organic Synthesis on the Early Earth, Origins of Life, 21, 3-17, 1991.

Coppens, F., Berton, R., Bondiou-Clergenie, A., and Gallimberti, I., Theoretical Estimate of NOx Production in Lightning Corona, J. Geophys.Res., 103, 10.769-10.785, 1998.

Donohoe, K.G., Shair, F.H., Wulf, O.R., Production of $\mathrm{O}_{3}$, $\mathrm{NO}$ and $\mathrm{N}_{2} \mathrm{O}$ in a Pulsed Discharge at 1 atm, Ind. Eng. Chem. Fundam., 16, 208-215, 1977.

Franzblau, E., and Popp, C.J., Nitrogen Oxides produced from Lightning, J. Geophys. Res., 94, 11,089-11,104, 1989.

Fraser, M.E., Tucker, T.R., Piper, L.G., Rawlins, W.T., $\mathrm{N}_{2} \mathrm{O}$ Production Mechanism from the Interaction of Discharge-excited Species, J. Geophys. Res., 95, 18611-18616, 1990.

Griffing, G.W., Ozone and Oxides of Nitrogen Production during Thunderstorms, J. Geophys. Res., 82, 943-950, 1977.

Hill, R.D., On the Production of Nitric Oxide by Lightning, Geophys. Res. Lett., 6, 945-947, 1979.

Hill, R.D., Rinker, R.G., and Wilson, H.D., Atmospheric Nitrogen Fixation by Lightning, J. Atmos. Sci., 37, 179193, 1980.

Hill, R.D., and Rinker, R.G., Production of Nitrate Ions and others Trace Species by Lightning, J. Geophys. Res., 86, 3203-3209, 1981.

Hill, R.D., Rinker, R.G., and Coucouvinos, A., Nitrous Oxide Production by Lightning, J. Geophys. Res., 89, 14111421, 1984.

Hill, R.D., Rahmin, I., and Rinker, R.G., Experimental Study of the Production of $\mathrm{NO}, \mathrm{N}_{2} \mathrm{O}$, and $\mathrm{O}_{3}$ in a Simulated Atmospheric Corona, Ind. Eng. Chem. Res., 27, 1264-1269, 1988.

Jebens, D.S., Lakkaraju, H.S., McKay, C.P., and Borucki, W.J., Time Resolved Simulation of Lightning by LIP, Geophys. Res. Lett., 19, 273-276, 1992.

Kasting, J.F., and Walker, J.C.G., Limits on oxygen concentrations in the prebiological atmosphere and the rate of abiotic fixation of nitrogen, J. Geophys. Res,. 86, 1147-1158, 1981.

Levine, J.S., Hughes, R.E., Chameides, W.L., Howell, W.E., $\mathrm{N}_{2} \mathrm{O}$ and $\mathrm{CO}$ Production by Electrical Discharges: Atmospheric Implications, Geophys. Res. Lett., 6, 557-559, 1979.

Levine, J.S., Brooke, R.R., Shaw, E.F., and Chameides, W.L., Aircraft Measurements of $\mathrm{N}_{2} \mathrm{O}$ Enhancement in Thunderstorms Lightning, EOS, Trans. Amer. Geophys. Union, 62, 290, 1981.

Levine, J.S., Gregory, G.L., Harvey, G.A., Howell, W.E., Borucki, W.J., Onvill, R.E., Production of Nitric Oxide by Lightning on Venus, Geophys. Res. Lett., 9, 893-896, 1982.

Mancinelli, R.L., and McKay, C.P., The Evolution of Nitrogen Cycling, Origins of Life, 18, 311-325, 1988.

Martinez, P., and Brandvold, D.K., Laboratory and Field Measurements of NOx produced from Corona Discharge, Atmos. Environ., 30, 4177-4182, 1996. 
Navarro-González, R., Romero, A., and Honda, Y., Power Measurements of Spark Discharge Experiments, Origins Life Evol. Biosphere, 28, 131-153, 1998a.

Navarro-González, R., Molina, M.J., and Molina, L.T., Nitrogen Fixation by Volcanic Lightning in the Early Earth, Geophys. Res. Lett., 25, 3123-3126, 1998 b.

Navarro-González, R., McKay, C.P., and Nna Mvondo, D., Nitrogen Crisis in the Early Biosphere and the Development of Biological Nitrogen Fixation, submitted for publication, 2001.

Noxon, J.F., Atmospheric Nitrogen Fixation by Lightning, Geophys. Res. Lett., 3, 463-465, 1976.

Noxon, J.F., Tropospheric $\mathrm{NO}_{2}$, J. Geophys. Res., 83, 3051-3057, 1978.

Postgate, J., Nitrogen fixation, Edward Arnold, Kent, Great Britain, ed. 2, pp. 73, 1987.

Ridley, B.A., Carroll, M.A., Gregory, G.L., Measurements of Nitric Oxide in the Boundary Layer and Free Troposphere over the Pacific Ocean, J. Geophys. Res., 92, 2025-2047, 1987.

Scattergood, T.W., McKay, C.P., Borucki, W.J., Giver, L.P., Van Ghyseghem, H., Parris, J.E., and Miller, S.L., Production of Organic Compounds in Plasmas: A Comparison among Electric Sparks, Laser-Induced Plasmas, and UV Light, Icarus, 81, 413-428, 1989.

Stark, M.S., Harrison, J.T.H., and Anastasi, C., Formation of Nitrogen Oxides by Electrical Discharges and Implications for Atmospheric Lightning, J. Geophys. Res., 101, 6963-6969, 1996.

Von Liebig, J., Une Note sur la Nitrification, Ann. Chem. Phys., 35, 329-333, 1827.

Wang, Y., DeSilva, A.W., Goldenbaum, G.C., and Dickerson, R.R., Nitric Oxide Production by Simulated Lightning: Dependence on Current, Energy, and Pressure, J. Geophys. Res., 103, 19149-19159, 1998.

Yung, Y.L., and Mc Elroy, M.B., Fixation of Nitrogen in the Prebiotic Atmosphere, Science, 203, 1979.

Zipf, E.C., and Dubin, M., Laboratory Studies on the formation of NOx Compounds and Ozone by Lightning, EOS, Trans. Amer. Geophys. Union, 57, 965, 1976. 